\title{
KAITAN FENOMENA EL NINO DENGAN BADAI DAN GELOMBANG PASANG
}

\author{
Oleh: \\ Suhadi Purwantara \\ Jurdik. Geografi, FISE UNY
}

\begin{abstract}
Abstrak
Artikel ini membahas kaitan Fenomena El Nino dengan badai atau gelombang pasang yang terjadi di beberapa wilayah dunia maupun di Indonesia. Dalam tulisan ini disajikan alasan-alasan penamaan badai yang ada di wilayah dunia, serta nama-nama badai baru yang ada di Indonesia. Kajian artikel ini dilengkapi dengan data berupa tabel, grafik, dan peta.
\end{abstract}

Kata kunci: Badai, Gelombang, El Nino.

\section{Pendahuluan}

Gelombang hingga setinggi dua meter akan melanda Pantai Sanur, Pantai Kuta, Tawang Mas, Widuri Pemalang, Pantai Pelabuhan Ratu, Kepulauan Seribu, Taman Rekreasi Pluit, dan Taman Impian Jaya Ancol (Warta Indonesia, 14 Mei 2010). Berita itu sebenarnya bukan hal yang baru. Kondisi alam seperti itu adalah relatif normal. Hampir sama dengan datangnya keadaan udara dengan suhu relatif panas pada bulan Oktober menjelang musim hujan. Atau lebih ekstremnya lagi hampir sama dengan pernyataan bahwa setelah jam 12.00 siang temperatur udara menjadi panas. Pendek kata datangnya gelombang setinggi dua meter yang akan melanda sebagian wilayah pantai di negeri ini sebenarnya sesuatu hal yang wajar, sesuatu yang alami.

Sangat alami, ketika udara bergerak dari wilayah dengan tekanan udara tinggi ke wilayah dengan tekanan lebih rendah. Pada bulan Januari, tekanan udara di wilayah Indonesia biasanya lebih rendah daripada tekanan udara wilayah Pasifik, atau daratan Asia. Pada bulan itu ada gerakan angin dari wilayah Pasifik sekitar ekuator menuju kea rah kepaulauan Indonesia yang bertekanan udara sekitar $1010 \mathrm{~mm}$ bar. Tekanan udara di Pasifik bisa mencapai $1020 \mathrm{~mm}$ bar, sedangkan di wilayah daratan Asia bisa mencapai $1030 \mathrm{~mm}$ bar. Oleh karenanya pada bulan Januari wilayah Asia Tenggara kedatangan massa udara yang jenuh uap air, yang siap menjadi hujan. Sebaliknya pada bulan Juli ada gerakan angin dari wilayah Australia ke wilayah Indonesia dilanjutkan ke wilayah Asia. Di wilayah daratan Asia tekanan udara relatif rendah, sehingga wilayah Asia mengalami musim penghujan. 
Musim penghujan yang terjadi di wilayah Indonesia sekitar bulan OktoberNovember hingga bulan April-Mei. Pada waktu itu banyak gerakan angin, terutama dari wilayah Pasifik, dan Asia Timur. Kedatangan angin itulah yang juga dapat menimbulkan bencana alam tersendiri, seperti angin topan, puting beliung, dan yang tidak kalah berbahayanya adalah angin yang dating dengan kecepatan tinggi dalam durasi yang lama dapat menimbulkan gelombang besar. Di pantai-pantai timur Jepang, Taiwan, Filipina sering di landa gelombang besar yang dapat merusak wilayah pantai terutama pelabuhan. Gelombang besar yang menerjang pantai dan merusak pelabuhan itu dalam bahasa Jepang disebut dengan Tsunami.

Tsunami yang diakibatkan oleh datangnya badai pernah menghantam pantai Selatan Dakka Bangladesh pada tahun 1990-an, yang sama sekali tidak diduga. Korbannya cukup besar mencapai puluhan ribu orang. Suatu peristiwa yang langka terjadi, namun masih sangat mungkin. Oleh karena itu walau kecil kemungkinan badai menerpa pantai selatan Jawa, tetapi tetap harus waspada. Kemungkinan tetap ada, terutama apabila ada fenomena El Nino maupun La Nina. Penyebab fenomena itu adalah perbedaan tekanan udara di atas laut yang ekstrem.

Bagaimanakah tekanan udara di permukaan laut di wilayah perairan kepulauan nusantara? Dimana saja gelombang besar terbentuk? Kapan musim gelombang besar? Apakah El Nino maupun La Nina mempengaruhi gelombang laut? Artikel ini mengkaji pertanyaan-pertanyaan di atas dan disajikan dengan banyak data yang berupa tabel, maupun gambar, dan peta.

\section{Agihan Tekanan Udara}

Tekanan udara berubah-ubah setiap saat. Sangat jarang ada tekanan udara sama sepanjang bulan, minggu, maupun hari. Tekanan udara dipengaruhi oleh temperatur udara. Di wilayah ekuator, ketika suatu wilayah sedang dilalui matahari maka udara cenderung panas dan tekanan udara berbanding terbalik dengan suhu udara, maka wilayah dengan temperatur tinggi, tekanan udaranya menjadi rendah.

Pada bulan Januari suhu udara di wilayah Indonesia rerata $29 \mathrm{C}$, tetapi jauh di Samudra Hindia bagian selatan hanya 26 C. Perbedaan tekanan udara dapat menimbulkan pergerakan udara, yang disebut dengan angin. Oleh karenanya gerakan angin cenderung dari wilayah Samudra Hindia ke wilayah ekuator atau ke utara. Tekanan udara yang ada di satu wilayah, misalnya wilayah peraiaran Indonesia, bisa berbeda dengan tekanan udara di wilayah perairan Lautan Hindia yang jauhnya beberapa ratus atau ribu kilometer di selatan Pulau Jawa. Perhatikan Gambar 1. 
Sea Surface Temp, week ending 10 Jan 10 Darwin RSMC (derived from Melbourne SOC andysis)

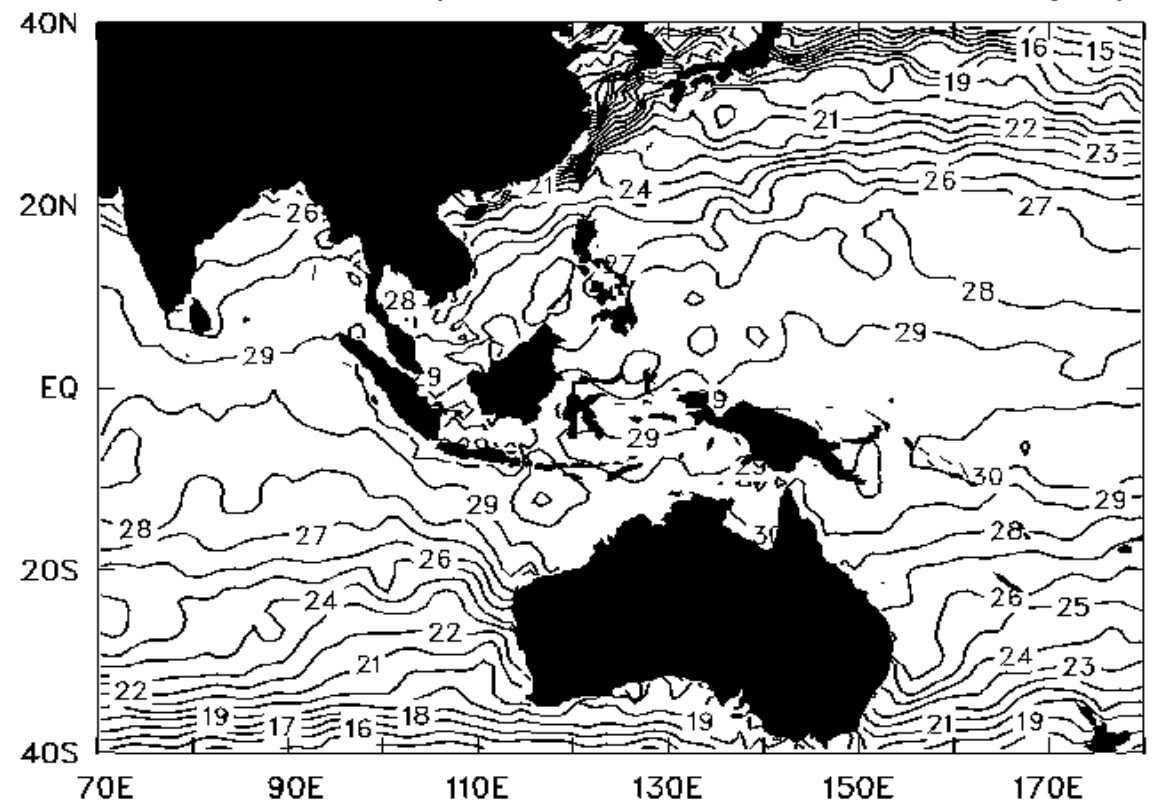

Gambar 1. Agihan Suhu Udara L. Hindia dan L. Pasifik (sumber NOAA)

Wilayah perairan Indonesia memiliki tekanan udara pada bulan Januari sebesar $1011 \mathrm{~mm}$ bar. Di wilayah lain, misalnya perairan Australia memiliki tekanan udara $1008 \mathrm{~mm}$ bar, sementara di perairan Jepang selatan mencapai $1020 \mathrm{~mm}$ bar. Berdasarkan beda tekanan udara itu dapat diperkirakan arah angin mengalir.

\section{Agihan Gelombang Besar}

Apa saja faktor pembentuk gelombang? Besar kecilnya gelombang sangat dipengaruhi oleh sedikitnya tiga faktor. Ketiga faktor itu adalah; 1) Kecepatan angin bertiup, 2) Lama angin bertiup, 3) Jarak angin bertiup bebas (fetch) (Sahala Hutabarat, 1982).

Dari data empiris, Breitschneider (King, 1963: 219), membuat grafik yang menghubungkan antara kecepatan angin, jarak angin bertiup, tinggi gelombang, periode gelombang, dan panjang gelombang.

Berdasarkan ketiga faktor itu, maka gelombang besar yang mungkin terbentuk adalah yang terletak di lepas pantai yang sering ada angin kuat dengan durasi angin bertiup cukup lama. Berdasar Gambar 1 dapat dicontohkan bahwa tekanan udara di atas permukaan air laut yang ada di 
Samudra Hindia yang berjarak 5000 km di selatan pantai Bangladesh, pada sekitar bulan Juli memiliki tekanan relatif tinggi. Pada gambar peta tampak pada tekanan 1026 mlbar, sedangkan tekanan udara di pantai Selatan Dakha hanya 1002 mlbar. Udara bergerak dari tengah samudra yang bertekanan tinggi ke arah utara menuju pantai selatan Bangladesh. Jadi pantai selatan negeri itu tidak mengherankan apabila menjadi sering dihantam badai, sekaligus gelombang pasang yang sangat besar. Sekitar 17 tahun yang lalu, tahun 1993 rakyat negeri itu berduka, sekitar 143 ribu penduduknya tewas oleh karena dihantam badai dengan kekuatan lebih dari 240 kilometer per jam, dan menimbulkan gelombang pasang hingga enam meter (Asia Calling, 2007). Bermacam badai yang menerjang negeri itu seperti badai Siklon Sidr, Siklon Aila sering memporakporandakan negeri itu. Badai Siklon Aila pada bulan Mei 2009 dengan kecepatan $90 \mathrm{~km}$ per jam menimbulkan gelombang pasang hingga 2,5 meter, memakan korban hingga 3200 orang tewas dan tiga juta orang kehilangan tempat tinggal(Media Indonesia, 2009, 26 Mei).

Demikian pula di wilayah lain, Eropa, seperti yang dilansir DetikNews 2 Maret 2010: "Korban Jiwa Akibat Badai menjadi 62 orang “. Badai yang menghantam Eropa iu dinamakan badai Xynthia. Di Jepang, badai atau topan yang popular adalah Topan Melor. Pada bulan Oktober 2009 Topan Melor menghantam Jepang dengan kecepatan 177 km/jam (Era Baru News, 8 Oktober 2009). Di Laut Cina Selatan akibat badai dengan kecepatan 200 knot atau sekitar $380 \mathrm{~km}$ per jam menimbulkan tinggi gelombang hingga enam meter (Ardava.Com, 12 Maret 2010: Pernah Hampir Hilang di Tengah Badai). Tahun 1839 (http://korananakindonesia.wordpress.com/2009/11/26/), gelombang pasang setinggi 40 kaki yang disebabkan oleh topan dahsyat menyapu kota pelabuhan di Coringa mengakibatkan setidaknya 20.000 rumah hancur dan 300.000 orang tewas. Ini bukan bencana pertama yang terjadi di Coringa: tahun 1789 terjadi tiga kali gelombang pasang yang juga disebabkan oleh topan dan menghancurkan kota di mulut sungai Ganga itu serta menenggelamkan hampir semua kapal-kapal dan mengakibatkan tewasnya 20.000 orang.

Demikian pula di wilayah negara adidaya Amerika Serikat, ada badai yang berbahaya, antara lain ada Tornado, dan yang terakhir cukup besar adalah Badai Katrina. Awalnya terbentuk pada 24 Agustus 2005, Katrina mempunyai tekanan pusat minimum sebesar $918 \mathrm{mb}$, jauh di bawah tekanan udara normal, sehingga merupakan sistem bertekanan tertinggi ketiga dalam sejarah Amerika Serikat. Menimbulkan pasang tinggi di banyak wilayah. Kerusakan yang diakibatkannya mencapai ratusan miliar dollar, dan diperkirakan menjadikannya badai Atlantik termahal dalam sejarah AS.

Bagaimana dengan badai di wilayah Indonesia? Menurut Zadrach L Dupe, Ketua Kelompok Riset Klimatologi, Departemen Meteorologi dan Geofisika ITB, untuk daerah sebelah selatan ekuator, aktivitas badai setiap tahunnya mulai 
pada September dan berakhir pada April tahun berikutnya. Untuk wilayah sebelah utara ekuator, aktivitasnya akan mulai pada Maret dan berakhir pada Oktober tahun berjalan. Selang waktu aktivitas badai di selatan dan utara ekuator ini berlangsung sesuai dengan pergerakan semu Matahari mengelilingi Bumi. Sebaliknya, pada bulan Maret-Oktober, wilayah Indonesia sebelah utara ekuator yaitu, Sumatera bagian utara, Kalimantan bagian utara, Sulawesi bagian utara, Maluku Utara, dan Papua bagian Utara, perlu mewaspadai badai yang terbentuk di perairan pantai barat laut Samudera Pasifik (daerah Filipina) dan Laut Cina Selatan. Bulan September sampai dengan bulan April, daerah Sumatera bagian selatan, Jawa dan Nusa Tenggara harus waspada terhadap badai yang berkembang di perairan utara-barat Australia seperti yang terjadi dengan badai tropis Fiona. Wilayah Jawa, Nusa Tenggara, Sulawesi bagian selatan, Maluku Selatan, dan Papua bagian selatan harus memberi perhatian terhadap badai yang terjadi di perairan utara- timur Australia, seperti yang terjadi dengan badai tropis Craig (Kompas, 28 Maret, 2003).

\section{Bagaimana Awal Penamaan Badai?}

Pada mulanya penamaan badai dilakukan berdasarkan cerita kisah atu juga bisa legenda. Sebagaimana penamaan pulau, danau, gunung, lokasi, dikenal dengan istilah toponimi. Contohnya dulu ada nama badai Antje. Awal nama itu diawali ketika pada sebelum tahun 1900-an, sebuah badai di Atlantik yang menghancurkan sebuah kapal bernama Antje diberi nama sesuai dengan kapal tersebut, yakni badai Antje. Pada perkembangan selanjutnya berdasarkan situs flobamor, penamaan badai cenderung feminis. Hal itu berawal dari para ahli meteorologi dari US Army Air Corp dan Angkatan Laut Amerika Serikat yang mayoritas laki-laki memberi nama badai-badai di Pasifik dengan para istri mereka. Pada 1979, WMO dan US National Weather Service (NWS) tidak hanya memberikan nama-nama wanita, tetapi juga menambahkan laki-laki dalam daftar nama badai.

WMO saat ini telah membuat enam daftar nama badai untuk kawasan Atlantik. Setiap daftar dipakai untuk satu tahun. Setelah tahun keenam, daftar pertama digunakan lagi pada tahun berikutnya. Sebagai contoh, jika badai Hanna digunakan pada tahun 2008, maka badai dengan nama yang sama baru boleh dipakai pada 2014. Setiap nama diawali dengan huruf berbeda yang diurutkan menurut abjad. Badai yang muncul pertama pada tahun bersangkutan diawali dengan huruf $A$, kemudian badai kedua $B$, ketiga $C$, dan seterusnya. Daftar nama ini mengecualikan huruf Q, U, X, Y, dan Z. Untuk nama perempuan dan laki-laki digunakan secara berselang-seling. Sebagai contoh tahun 2008, yakni dimulai dari Arthur, selanjutnya Bertha, kemudian Cristobal, disusul Dolly. Selanjutnya, berturut-turut, Edouard, Fay, Gustav, Hanna, Ike, Josephine, Kyle, Laura, Marco, Nana, Omar, Paloma, Rene, Sally, Teddy, Vicky, dan Wilfred. 
Di kawasan Pasifik Timur Laut nama berawalan X, Y, dan Z boleh digunakan. Berbeda dengan yang lain, nama-nama yang berawalan dengan ketiga huruf tadi muncul setiap dua tahun. Sebagai contoh tahun 2008, 2009, 2010, 2011,2012, dan 2013 akan muncul berturut-turut Zeke, Zelda, Zeke, Zelda, Zeke, dan Zelda lagi. Ketentuan ini juga dipakai oleh Kawasan Australia Barat, Australia Utara, Australia Timur, Kepulauan Fiji, dan Papua Nugini. Jadi, andaikan deretan badai tahun tertentu berakhir dengan nama yang diawali dengan huruf L, misalnya saja Lisa, maka badai pertama tahun berikutnya dijuluki nama yang diawali dengan huruf $\mathrm{M}$, misalnya Marcus.

Menurut ketentuan WMO, nama badai yang telah menimbulkan kerusakan hebat, sehingga menimbulkan kerugian nyawa, harta, dan benda yang amat besar, tidak akan dipakai lagi. Sejak 1954, terdapat 40 nama yang dipensiunkan dari daftar nama badai. Misalnya, badai Agnes, Camille, Flora, Jane, dan sebagainya. Eliminasi nama dari daftar ini diputuskan oleh sidang tahunan WMO, dan selanjutnya digantikan dengan nama lain. Pertimbangannya, antara lain didasarkan pada alasan psikologis. Contoh eliminasi dapat dilihat pada daftar 2001, Luis tidak ada lagi karena telah diganti dengan Lorenzo, Michelle menggantikan Marilyn, Olga menggantikan Opal, dan Roxanne digantikan oleh Rebekah. Pada daftar 2002, nama Cesar digusur Cristobal, Fay menggantikan Fran, dan Hanna menggantikan Hortense. Daftar 2004 tercatat, Gaston menggantikan Georges, dan Mitch digantikan oleh Matthew. Dalam daftar 2006, Keith sudah raib karena digantikan Kirk. Sedangkan, badai Katrina yang meluluhlantakkan New Orleans tahun 2005 lalu yang sedianya muncul lagi tahun 2011, dihapus dan diganti dengan Katia (www.flobamor.com).

\section{Bagaimana dengan di Indonesia?}

Badai tidak akan melintasi Indonesia, tetapi hanya menerima dampak tidak langsung dari badai tersebut (Achmad Zakir, BMG). Menurut Zakir suatu Pusat Peringatan Siklon Tropis yang telah ditunjuk sebelumnya oleh WMO berwenang memberi nama badai ini dan menyebarkan peringatan ke seluruh dunia. Mendekati bulan September-Oktober, perairan Filipina menjadi wilayah yang mesti diwaspadai. Meski badai tropis selalu reda begitu mendekati khatulistiwa, ekor badai masih sangat mungkin menyapu kawasan Sumatera Utara, Sulawesi Utara, Maluku Utara, atau Kalimantan bagian Utara. Sebaliknya, pada periode September-April, saatnya mewaspadai badai tropis di kawasan utara Australia. Laut Timor merupakan kawasan di perairan terdekat Indonesia yang paling berbahaya.

WMO mencatat, Indonesia telah memberi nama-nama badai yang menjadi tanggung jawabnya pada 2008. Nama-nama badai itu lain seperti di AS. Jika di sana menggunakan nama laki-laki dan perempuan, di Indonesia 
menggunakan nama bunga, yakni Anggrek, Bakung, Cempaka, Dahlia, Flamboyan, Kenanga, Lili, Mawar, Seroja, dan Teratai.

Di Indonesia, masih menurut flobamor, selama ini sudah banyak dikenal nama-nama badai, atau masyarakat Indonesia lebih member nama yang tidak menakutkan, yaitu hanya angin. Contohnya angin Gending, dan Bohorok. Penamaan angin atau badai selama ini berada di bawah otoritas World Meteorology Organization, dengan ketentuan-ketentuan khusus. Ketentuanketentuan itu antara lain bila kecepatan angin di atas $60 \mathrm{~km}$ per jam. Pada tahun 2008 ketika Bengkulu diterjang badai dengan kekuatan hingga $120 \mathrm{~km}$ per jam, BMG langsung member nama Badai Durga. BMG pernah mengusulkan nama-nama seperi badai Togog, badai Durga, badai Rahwana, tetapi kemudian ditarik lagi karena nama-nama itu berkonotasi negatif yang cenderung merusak. Belakangan BMG mengusulkan nama-nama badai dengan nama bunga seperti tersebut di atas.

\section{Wilayah perairan berpotensi terjadinya badai tropis}

Menurut Iwan Dahnial, secara umum wilayah terjadinya badai tropis dikelompokkan atas 2 wilayah utama yaitu belahan Bumi Utara dan belahan Bumi Selatan. Badai tropis yang terjadi di belahan Bumi Utara, arah putaran badainya searah putaran jarum jam, sedangkan di belahan Bumi Selatan arah putaran badai tropis berlawanan arah putaran jarum jam. Ada tujuh wilayah perairan (lautan) sangat berpotensi terjadinya badai tropis , yaitu; 1) Barat Laut Samudera Pasifik, 2) Timur Laut Samudera Pasifik, 3) Barat Daya Samudra Pasifik, 4) Utara Samudera Hindia, 5) Tenggara Samudera Hindia, 6) Timur Laut Samudera Hindia, 7) Utara Samudera Atlantik.

\section{Musim badai tropis}

Puncak terjadinya aktivitas badai tropis di seluruh dunia terjadi pada akhir musim panas yakni ketika laut mencapai temperatur paling hangat. Namun di setiap wilayah terjadinya badai tropis, pola musimnya berbeda. Di wilayah Atlantik Utara, musim badai tropis dimulai 1 Juni hingga 30 Nopember. Puncaknya terjadi pada awal September. Di wilayah Timur Laut Pasifik pola musimnya sama dengan wilayah Atlantik Utara, namun periodenya lebih panjang, wilayah Barat Laut Pasifik badai tropis di wilayah ini berlangsung setahun penuh, dengan puncaknya pada awal September dan aktifitas minimum pada bulan Februari, di wilayah Utara Samudera Hindia musim badai tropis di wilayah ini berlangsung dari bulan April sampai bulan Desember, puncaknya terjadi pada bulan Mei dan Nopember. Secara umum, aktivitas badai tropis di belahan Bumi bagian Selatan berlangsung dari akhir Oktober hingga Mei, dengan puncak aktivitas terjadi pada pertengahan Februari hingga awal Maret. (http://iwandahnial.wordpress.com/2008/09/10/badai-tropishurricane-typhoon-tropical-cyclone/). 


\section{El Nino dan La Nina}

Apakah El Nino dan La Nina itu? El Nino dan La Nina dalah suatu fenomena kelainan atau penyimpangan atau anomali iklim yang, yaitu adanya perbedaan temperatur dan tekanan udara yang tidak normal. Dalam bahasa Latin Amerika, El Nino berarti si anak natal, sedangkan La Nina berarti si nona kecil. Diberi nama si anak natal (corrientes de niño), berawal dari ceritera nelayan Peru yang selalu kehilangan ikan pada setiap bebeapa tahun sekali di seputar hari Natal, karena tiba-tiba air laut menjadi lebih hangat daripada biasanya, sehingga tidak ada ikan yang bisa diambil (Strahler, 1987: 142). Gejala kejadian El Nino dan La Nina sudah berlangsung sejak lama, maksudnya bukan terjadi pada akhir abad kedua puluh saja, tetapi telah terjadi ratusan tahun yang lalu. Namun para pakar klimatologi baru dapat memiliki jawaban fenomena alam itu belum lama ini, atau pada akhir abad ke dua puluh. Berdasarkan data meteorologi yang berupa tekanan udara dan temperatur udara di atas permukaan air laut sejak tahun 1875, ternyata sebenarnya telah terjadi berulang kali fenomena El Nino dan La Nina.

Secara meteorologis kejadian El Nino dan La Nina ditunjukkan oleh Indeks Osilasi Selatan atau Southern Osccilation Index (SOI) dan suhu permukaan laut di Samudra Pasifik (WMO, dalam Bambang Irawan, 2006). Indeks itu didasarkan oleh perbedaan tekanan udara di atas permukaan laut antara Tahiti dengan Darwin yang tidak seperti keadaan normal. Oleh karena itu dinamakan osilasi, suatu istilah yang dapat dimaknai sebagai gangguan, penyimpangan atau anomali. Untuk kata Selatan, karena indeks ini dikalkulasi berdasarkan dua data yang berada di wilayah sebelah selatan Ekuator, yaitu di Haiti yang terletak pada 17 LS 150 BB, dan Darwin yang terletak pada 12 LS, 130 BT. Nilai SOI dihitung menggunakan formula yang dirumuskan oleh Troup (1965), setelah direvisi oleh National Climate Centre (NCC) berikut.

$$
\begin{aligned}
& \text { PA(Tahiti) - PA(Darwin) } \\
& \text { SOI = - } \times 10 \\
& \text { Std.Dev.Diff }
\end{aligned}
$$

\section{Keterangan:}

PA adalah rerata bulanan dikurangi rerata jangka panjang (puluhan tahun)

Std.Dev.Diff adalah stándar deviasi dari perbedaan

Hasil dari perhitungan dengan rumus di atas dapat menghasilkan nilai positif maupun negatif. Apabila tekanan udara di Tahiti lebih besar daripada tekanan udara di Darwin maka SOI memiliki nilai positif, sebaliknya apabila tekanan udara lebih besar di Darwin, maka SOI negatif. Nilai indeks yang berpengaruh terhadap fenomena EI Nino dan La Nina, yaitu apabila rerata SOI lebih dari empat bulan, dan besaran indeks lebih besar dari 10. 
Nilai indeks osilasi selatan setiap hari dapat berubah-ubah, dari minus hingga beberapa digit di bawah nol, bahkan bisa pula positif hingga lebih dari sepuluh. Contoh dapat dilihat pada Tabel 1.

Tabel 1. Tekanan Udara Permukaan Laut di Tahiti dan Darwin, serta SOI

\begin{tabular}{|c|c|c|c|c|}
\hline Tahun & Hari & \multicolumn{1}{|c|}{ Tahiti } & Darwin & SOI \\
\hline 1998 & 151 & 1015.28 & 1013.80 & -0.32 \\
\hline 1998 & 150 & 1016.87 & 1013.55 & 13.75 \\
\hline 1998 & 151 & 1016.62 & 1013.95 & 8.76 \\
\hline 1998 & 152 & 1014.91 & 1013.75 & -0.89 \\
\hline 1998 & 153 & 1013.31 & 1012.00 & 0.15 \\
\hline 1998 & 154 & 1014.73 & 1010.90 & 17.91 \\
\hline 1998 & 155 & 1016.82 & 1010.70 & 33.98 \\
\hline
\end{tabular}

Sumber : State of Queensland (Department of Environment and Resource Management) 2010

Dalam sajian data pada Tabel SOI bulanan pada tahun 1997 dimulai dari bulan Maret besaran indeks mulai menunjukkan angka negative, yaitu -7 . Demikian selanjutnya -14,3 pada bulan April, -19,0 bulan Mei, berlanjut hingga bulan Mei tahun 1998, berarti terjadi SOI negative selama 15 bulan, tetapi satu bulan mendekati angka nol, sehingga dihitung hanya 14 bulan. Pada pertengahan tahun 1998 terjadi keadaan sebaliknya. Mulai bulan Juni nilai SOI berbalik positif, dimulai dari angka 8,2 , kemudian 12,8 pada bulan Juli, 9,7 pada bulan Agustus, dan seterusnya hingga bulan Mei 1999 tetapi angka SOI sudah mendekati nol, yaitu 0,9.

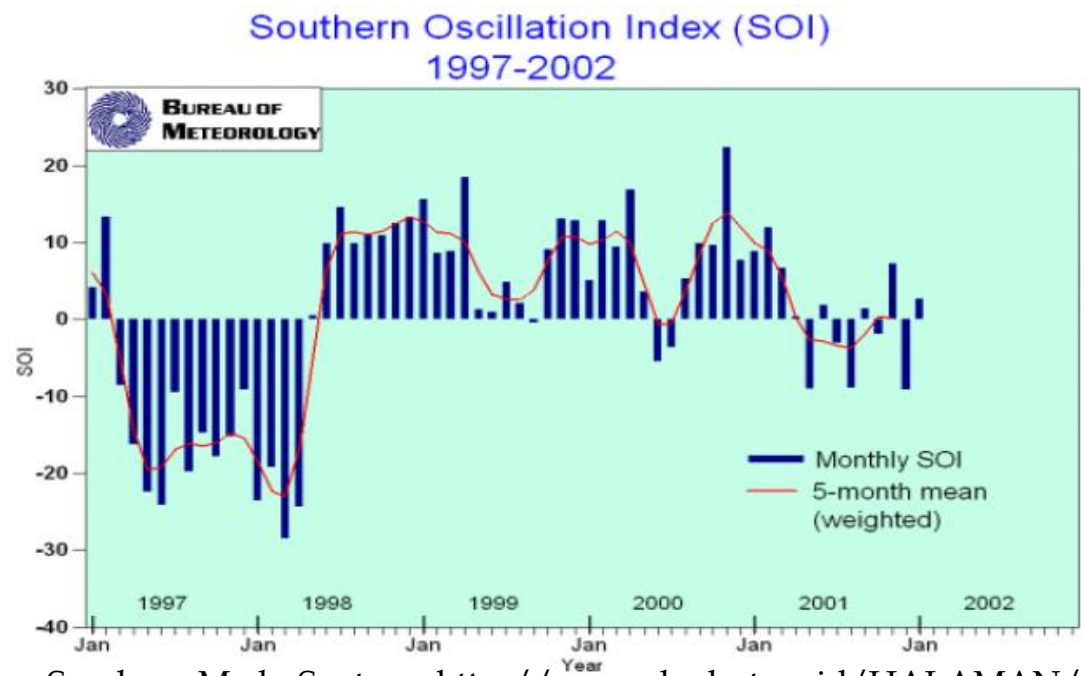

Sumber: Medy Santosa, http-//www.dephut.go.id/HALAMAN/ PDF / ffm14.pdf 


\section{Seberapa besar El Nino dan La Nina mempengaruhi gelombang?}

Besarnya perbedaan tekanan udara adalah factor utama yang dapat menyebabkan pergerakan udara. Angin yang bergerak cepat itulah yang menjadi factor penyebab tingginya gelombang laut. Pada grafik Gambar 2 ditunjukkan bahwa semakin tinggi kecepatan angin, pada factor lain yang sama, maka tinggi gelombang akan semakin besar. Peristiwa di pantai selatan Bangladesh telah dapat menjawab. Angin yang melaju dengan kecepatan 90 $\mathrm{km}$ per jam menimbulkan gelombang pasang hingga 2,5 meter, sedangkan di waktu yang lain angin dengan kecepatan $240 \mathrm{~km}$ per jam menimbulkan gelombang setinggi 6 meter. Cepat lambatnya angin bergerak tentu saja sangat dipengaruhi oleh tinggi rendahnya perbedaan tekanan angin dari wilayah satu dengan wilayah lainnya. Oleh karenanya perbedaan tekanan yang rendah juga menimbulkan pergerakan udara dengan kecepatan rendah, tetapi perbedaan tekanan udara yang sangat tinggi dapat menimbulkan angin dengan kecepatan sangat tinggi.

Di Indonesia pengaruh fenomena El Nino dan La Nina tidak seburuk dampak gelombang pasang seperti yang ada di Bangladesh. Ketinggian gelombang di beberapa pantai hanya pada kisaran dua meter saja. Meskipun demikian sudah harus menjadi perhatian para pekerja laut, terutama para nelayan dan kapal-kapal penghubung. Hal itu penting diwaspadai karena tidak jarang beberapa perairan sering memakan korban, dengan tenggelamnya beberapa kapal penumpang seperti yang telah terjadi di dekat Pulau Mandalika, Pantai Jepara Laut Jawa (DetikNews 30 Desember 2006), Perairan Aru Papua barat (Februari 2010, video.tvone.co.id/arsip), Dekat Tanjung Perak Surabaya (5 Mei 2010, Beritajatim.com).

\section{Penutup}

Fenomena El Nino lebih erat kaitannya dengan berkurangnya jumlah curah hujan terutama di wilayah Asia Tenggara. Fenomena La Nina cenderung berdampak bertambahnya curah hujan. El Nino yang terjadi pada tahun 1997 sangat terasa dampaknya di wilayah Indonesia. Kekeringan panjang pernah melanda wilayah Indonesia. Banyak terjadi kebakaran hutan di beberapa wilayah Indonesia seperti yang banyak terjadi di Sumatera dan Kalimantan. Musim kemarau yang biasanya paling lama hanya enam hingga tujuh bulan, pada waktu itu mencapai sekitar 10 hingga 12 bulan.

Terkait dengan badai dan gelombang pasang, pada bulan-bulan tertentu memang sedikit ada pengaruhnya, tetapi kurang begitu terasa. Bangsa Indonesia harus bersyukur dampak El Nino dan la Nina tidak sampai menimbulkan badai dan gelombang besar. Indonesia, berdasarkan letaknya bukan menjadi lintasan badai atau siklon tropis dengan kekuatan sangat besar seperti yang terjadi di beberapa wilayah negara lain dengan kecepatan hingga lebih dari $200 \mathrm{~km}$ per jam. 


\section{Daftar Pustaka}

Asia Calling. (2007). Kepedihan Bangladesh Akibat Bencana Alam Kedua Tahun Ini. Berita.

Bambang Irawan. (2006) Fenomena Anomali Iklim El Nino dan La Nina: Kecenderungan Jangka Panjang dan Pengaruhnya Terhadap Produksi Pangan. Artikel. Forum Penelitian Agronomi. Vol 24. No. 1 Juli 2006: 2845.

Beritajatim.com. (2010,). Lima Korban Diperkirakan Dekat Lokasi Tenggelam. Diakses dari www.beritajatim.com tanggal 5 April 2010

Damen, M. C. J. (1989). Cities and Environmental Earth Sciences. Enschede: International Institute for Aerospace Survey and Earth Sciences. Netherland: ITC.

DetikNews (2006). Kapal Senopati Tenggelam di Pulau Mandalika Jepara. Diakses dari detkNews.com edisi 30 Desember.

Hansen, A. (1984). Landslide hazards Analysis. Geotechnical Control Office, London: University of London.

King. (1964). An Introduction to Oceanography. New York: McGraw Hill Book Company.

Media Indonesia, (2009). Badai Aila menghantam India Timur dan Bangladesh. Diakses dari http://www.yiela.com/details/449176/badai-aila-hantambangladesh. tanggal 30 Desember 2009

Medy Santoso, Liam Fogarty, dan Bert Booger, "Sistem Peringatan Dini dan Penentuan Tingkat Bahaya Kebakaran di PT. INHUTANI 1", diakses dari http-//www.dephut.go.id/HALAMAN/PDF/ffm14.pdf Ray K. Linsley. JR; (1989) Hidrologi Untuk Insinyur. Jakata: Erlangga

Sahala Hutabarat, (1982). Pengantar Oseanografi. Jakarta: UI Press.

Strahler (1987), Modern Physical Geography, New York : John Willey \& Sons

Verstappen, H. Th., (1985). Applied Geomorphological Survey and Natural Hazard Zoning. Enschede: ITC.

video.tvone.co.id/arsip Februari 2010,), Kapal Tenggelam di Perairan Aru Papua Barat

Warta Indonesia, 14 Mei 2010. Dampak El Nino: cuaca Ekstrem Bakal landa Indonesia

www.flobamor.com. 2008. Sang “Gadis” dan “Bunga” Pembawa Malapetaka!! 
|| Kaitan Fenomena El Nino dengan Badai dan Gelombang Pasang

Zadrach L Dupe, 2003. Badai Tropis dan Cuaca Ektrem di Indonesia. Kompas 28 Maret 2003.

(http://iwandahnial.wordpress.com/2008/09/10/badai-tropis-hurricanetyphoon-tropical-cyclone/).

(http://korananakindonesia.wordpress.com/2009/11/26/), 